\title{
The Auditing Process Reform in the Jordanian Bureaucracy
}

\author{
Dr. Rami Tbaishat \\ Assistant Professor of Public Administration, \\ Department of Public Administration, \\ Faculty of Economics and Administrative Sciences, \\ Yarmouk University, Irbid, Jordan
}

DOI: https://doi.org/10.36941/ajis-2021-0039

\begin{abstract}
The aim of the research is to systematically conduct a methodical analysis of policy reforms in Jordan and study the perceptions and features of such a reform. The primary purpose of this review study will be to concentrate on the auditing issues within the system for developing policies and guidelines and to identify possible weaknesses and deficiencies. The investigation of this study used the diagnostic-analytical analysis of the auditing system in the political process to recognize the underlying flaws and weaknesses. In this analysis process, pattern matching is a well-known technique in this type of study, where a certain type of outcome may be known in several cases and the study concentrates on how and why these results occur in each case. The study found that the degree of authority assigned to both the government and its regulatory structure is clearly the main variable that can impede and encourage successful standards of transparency and responsiveness. Jordan's latest endeavor to reach agreement on the role, functions and power of the government has opened the door to the quarrels that endanger the regime's stability. This research will also take into account the environmental conditions under which the governance structure functions effectively and how Jordan can channel its efforts towards achieving productivity in the public service, with particular emphasis on the auditing process.
\end{abstract}

Keywords: Performance Management, Bureaucracy, Jordanian government, Policy formulation, Auditing

\section{Introduction}

Jordanian government is dealing with substantial challenges include preserving peace and harmony, increasing deep poverty, maintaining healthy and equitable development and ensuring legal, effective, open and participatory governance (UN Human Development Report 20o8). The government need to deal with inequality issues, to eradicate inequalities and to resolve bribery in order to guarantee accelerated justice that the kind of government is required to increase growth rates. It may be observed that in examining the transition efforts to democracy, the reform efforts focus either on broad issues of systematic constitutional change or the role traditional institutions and actors, such as executives, policy makers, political parties or international factors, played or assigned to them. The governmental bureaucracy and its potential to influence the content and direction of change and innovation processes effectively in the policy making process have little or no attention. The ability of the system to address the conflicting objectives of economy efficiency and rationality, based on legitimacy, must 
be based on good governance on broad participation and equality in the distribution and access to public services in the processes of public policymaking (Boyd, N., and B. Nowell. 2020).

In order to strengthen the understanding of the functional existence of the government and management of the system, the introduction of new logical methods to decision-making is highly recommended. The legitimating of the administrative system was the right place to address conflicts of interest, creating a technocratic culture (Piatak, and Holt. 2019).

Woodrow Wilson tried to answer these concerns by articulating the dichotomy of government and public policy. "Government is about policy, and administration is about enforcing such policies" (Agarwal, 2018). Political officials take political decisions on public policy and then determine how these policies can be applied most effectively. Unfortunately, it is much harder to achieve this easy division of labor than to say. The statutory or presidential rule provisions are never so clear that the regulatory body just leaves the technical details on the execution.

In the institutional structure, the Government chain of command is so rigid that top leaders are not likely to share or empower their constituents (Tbaishat, 2015).

The governance system is evolving as the transition from state to business (Biesbroek, Peters, and Tosun. 2018) has been taken into account. The framework is shifting. This reform centers on organizational activities that go beyond policy boundaries, away from the bureaucratic state and the overt provision of services for third-party agencies (Gerston, 2015).

In addition to this, we move beyond government limits, that is, we have less involvement and less importance for the ways in which we govern ourselves (Blessett, B. 2018) with traditional government mechanisms and institutions.

Nevertheless, the overarching difficulty of these changing times has recently begun to study the conscience of thinkers and practitioners. The following refurbishment is considered: is traditional bureaucracy sufficient to cope with changes such as social, economic and political? Is it geared to national development, which is practically every government's expressed objective? Should we not switch the emphasis on merely maintaining the system on active development? Should the innovative aspects of government administration not be given more attention?

Public administration, political science, economics and other related disciplines do not neglect concepts for bridging transformative processes from shortage to plenty. The obvious question, however, is what would lead to national development in one type of administrative reform? If this question were satisfactorily analyzed, the necessary growth expected in the last decade would have been achieved without difficulties.

\section{Literature Review}

Investigating the position of confrontation between departments directly involved with administration management and government auditing, (Dias and Moody 2007) states that a function is a pattern of behavior seen as intended by an employee. It ensures officials often use the concept of positions and responsibilities that others convey to them to assess the activities and requirements aligned with their specified occupations. Failure to meet different standards will lead to conflict and stress.

Practitioners with rule enforcing roles assume that the job conduct that the organization requires with respect to the execution of policies is in accordance with its beliefs, principles, or actions (Grimmelikhuijsen, Jilke, Olsen, and Tummers. 2017).

(Tbaishat et al., 2018) assessed four key forces in global waves of government reform were identifying in his article Reforming Policy Roles in the Jordanian Policy Making Process: global economic competition, demotivation, the information revolution and the current deficit. The role of the modern administrative state in shaping and reorganizing society and to guide, regulate and control economic and social development is taken into account. Doubts about governance are not only based on the state's limited financial capability. These are the product of profound political debates surrounding the nature of the state and its functions and changing control over the state and its priorities and the tension between them and what the State needs or ought not to do. 
When articulating his dichotomy of the division of labor (Angranof and Yildis, 2006) he tried to answer these questions. "Politics is linked to the politics or manifestations of the will of the State and government has to do with the execution." Political leaders would decide on policy, and then career officials would determine which way to implement these policies most effectively. The apparent division of labor between political and management is an enticing idea that, regrettably, is completely unrelated to fact.

The dynamics of governmental system change in forms caught as the "shift from state to democracy" (Kernaghan, 2010). The transition involves bureaucratic activity which shifts away from government structures, administration, the provision of services and the central government to socalled government by third parties. In other words, the ways we rule go beyond state boundaries, i.e. traditional mechanisms and government institutions are less engaged in the ways we govern ourselves and less central in them.

Propagated by the definition of new public management (NPM), (Light, 2019) claimed that the enhanced hierarchical specialization of administrative functions in many countries through NPM changes often was combined with a simpler separation of political and administrative functions, leading towards a finer and systemic division of policy advice, regulatory and control activities. Simply put, regulatory theories and reformist indicated, instead of being involved in the political decisionmaking process, that administrative players, like agencies with a lack of length, should focus on policy implementation.

(Talbot, 2004) similarly, notes that' the Next Steps ' aim was to better describe the respective functions of ministers and officials, ministers responsible for establishing policies and officials responsible to do so having the autonomy to do so. Reformers in Great Britain and the Netherlands have suggested often that the restructuring of public functions of institutions would lead to improved governance and better delivery of programs and to the distancing of public services within organizations contributing to job leadership and accountability through getting services back to the individual by ' letting administrators handle and control them.

(Lawson, 2006) proposed that good governance needs to be able to balance the competing goals of economic efficiency and realism with the goal of credibility based on broad public-policy involvement and fairness in the delivery and access to public services.

(Stolk and Wergrich, 2008) claimed that change actively seeks to establish better links in order to balance political and budgetary goals and to make sure they reinforce one another. The growing position of the budget ministries is a positive growth. They move away from their traditional role as nay-sayers and build know-how on cost reduction and productivity steps. We are therefore best able to advise governments on increasing administrative costs without growing programmers.

\section{Research Methodology}

The investigation of this study used the diagnostic-analytical analysis of the auditing system in the political process to recognize the underlying flaws and weaknesses. In this study, the important characteristics of rival policy reform explications have been examined and presented. In this analysis process, pattern matching is a well-known technique in this type of study, where a certain type of outcome may be known in several cases and the study concentrates on how and why these results occur in each case. A lack of circumstances under which research and development can be used by society is a common policy issue.

This framework thus helps to clarify and appreciate the strategies and intentions behind contemporary governments ' changes and reorganizations. The design also offers conceptual frameworks for study of democratic government and public administration structure and reorganization.

The analysis and investigation focused on the conditions under which the governance structure functions effectively and how government could employ its human and material resources towards public service efficiency. This study was therefore conducted to verify certain aspects of the 
relationship to ends by focusing on policy auditing as well as on their public interest impact.

Further the study investigates aspects in which the reform framework could explain the distribution of accountability for policy making and execution between lawmakers, political leaders and skilled public officials.

towards public service efficiency. This study was therefore conducted to verify certain aspects of the relationship to ends by focusing on policy auditing as well as on their public interest impact.

Data for this study was collected from secondary resources, national and international to analyze and assess the Jordanian experience of administrative reform, like the Ministry of Finance and the Audit Bureau laws and reports. Moreover, data obtained from international organization reports like UNDP and the World Bank for the period 2015- 2018 to get information about the main findings and assessments.

\section{Results}

There is an impressive array of formal powers bestowed on the Executive Branch that positions the Prime Minister at the core. He has been asked to perform a number of roles that enable him to extend his capacity in the policy system to convince and influence other important players. According to the Constitution, the Council of Ministers may enact by-laws to ensure that public funds and warehouses are allocated and expended. In fact, to satisfy and be able to cope with the increasing demands on his office.

The state has long-lasting consequences for public administration, with its institutional development. The State extends the scope of its activities on an institutional basis to include business, industrial, environmental, political, public health, social security, education and welfare; increasing fragmentation is the trend of success in the public sector. Prior to the launch of ambitious development policies and programs, there was no integrated master plan. There has not been any increase on rationality-based scope of the government's functions, size, costs or relative power; and a barrier for attempts to address changes from a technical perspective has been a dysfunctional transformation of the public sector. This contributes to the uncomfortable coexistence of public policies and organizations designed to address competing goals, unclear authority and significant differences in the availability of resources. The possibility to have some effective Policymakers in general and through public participation in particular, planning, monitoring and coordination became minimal.

The question is how to govern the auditing institutions. What are the government's financial management functions? Who's making decisions? How much authority and accountability is provided for each government branch regarding the auditing process?

Jordan has initiated the reform process because of some recent economic and financial problems. This reform was made even more urgent by the international aid organization due to the financial crisis facing the government.

The study showed that the following institutions directly participate in bureaucratic control and government auditing.

1- The Internal Auditing

The internal control role is delegated to the Finance Ministry, and the Finance Minister is responsible for controlling the budgets of other departments and public authorities, ensuring that each of them complies with financial regulations on accounting and financial transactions (World Bank Report, 2015). The implementation of the Bylaw is also the responsibility of each minister concerned.

To achieve its objectives, the Ministry of Finance controls spending to ensure compliance. It also monitors the collection of revenues in order to ensure that the appropriate amounts were collected at the appropriate time and deposited in public treasury according to the laws of the applicable law.

Surprise checks on the cash flow inventory and other financial transactions may be carried out by the Ministry of Finance. The government has issued 1992 circular No (31) to enable the 
role of internal control in government units to assist higher management to control public funds.

Internal control unit's operations have been built up in various ministries and public agencies and the steps necessary to implement the internal unit role have been taken (World Bank Report 2016). The guidelines were given to insure that the internal control targets were met, including capacity building, strengthening public funds monitoring and improving internal audit processes.

2- The External Auditing

Article (119) of the Constitution of Jordan is used as the basis of the Audit Bureau Law No. (28) of 1952 for the establishment of the Audit Bureau to oversee the income, costs and methods of spending of the State. The Bureau conducts following duties, based on the Law and its modifications like the surveillance and auditing of trusts, interest transactions, loans and store holders, the supervision of income and expense of that government, and the advice on accounting matters to the public agencies that come under its audit.

As an arm of the government, the audit bureau has the functions of external supervision of the operations of ministries, public agencies, public departments, and municipalities to study, investigate and examine financial and administrative activities of the government departments.

The Jordanian government asked the UNDP office in Jordan to determine why and how far ineffective and corrupt Jordan is. It focused on government weaknesses in the legislative framework, regulations, institutions, management systems, policies and procedures to promote corruption and inefficiency.

Audit rating assessed by the Office of UNDP of the operation of government as unsatisfactory or partially satisfactory, which means "internal controls, governance and risk management processes were inadequately established and functioning not well. No issues were identified that would significantly affect the achievement of the objectives of the audited entity.

The UNDP office included the following notes in the report:

1. Estimates of the budgetary cost of new initiatives and ongoing costs of government policies are not clearly distinguished in the budget document (the budget speech identifies in a broad manner the main government policies explaining major changes in budget revenue and spending). It also contains general statements on new government priorities. The budget document, however, do not provide a quantification of the cost of new government spending programs nor clearly distinguish them from the cost of ongoing government activities.

2. The sensitivity of budget estimates to changes in economic variables is not assessed and fiscal risks are not discussed within the budget. (The budget documents do not include a sensitivity test of fiscal aggregates in the face of changes in economic parameters or other uncertainties, nor an analysis of the principal contingent liabilities.

3. The basic accounting and internal auditing procedures in place are not sufficient to maintain an adequate control of government spending. (While reasonable internal control procedures are in place, accounting arrangements fall short of international best practice. There is no comprehensive general ledger based on sound chart of accounts nor an integrated information system of the financial management of government operations.

4. The internal and external audit and financial management practices are not well coordinated. (There is no internal audit function as defined by international standards, namely the auditing of the quality and effectiveness of the ministry financial management system (as the coordination between the main departments of the ministry involved in the government financial management is still weak. As a result, there is not an effective coordination between cash and debt management.

Key issues and recommendations, both ranked important priority, which means "Action is required to ensure that the operation of the government activities is not exposed to significant risks. Failure to take action could result in negative consequences for actions of the government." These 
recommendations include actions to address the uncertainty surrounding these actions United and the need to address the incorrect recovery of the internal and external audit. (UNDP report, 2014)

\section{Conclusion}

The internal and external independent audits describe auditing as complying with legislation and regulations; and they inappropriately suit each other's actions and there is no proof that they are learning from the international best practices. As mentioned elsewhere, the Ministry of Finance should delete its internal audit function because its internal audit is the responsibility of the Ministry of Finance, which places the internal auditors in government units to act on their behalf instead of on behalf of the department manager. Simultaneously, internal control should include activities such as tracking the quality of duties and responsibilities of workers. However, the auditing services run with few impacts, either as the control mechanism of the operations of the executive branch or as a supervisory device, on how public administration functions. The heavy reliance on legal approaches to audit and management issues limited the direction or focus of any policy analysis. Their work is considered technically restricted so as to ensure compliance with the rules of law or proper procedures. The lack of focus in government legislation and rules, management systems, policies and procedures on causes and degree of inefficiency and bribery activities helps to promote corruption and inefficiency.

The need to reduce government operations is recognized (Black Den and Driemeier, 2013). This recognition has led the budget Department to try and introduce a budgeting system in which operational management is increasingly deregulated, with fewer controls imposed on the center of government due to the lack of a bureaucratic model.

The virtues of specialization illustrated by bureaucracy seen as essential to mass production and most cost-effective way of achieving difficult goals (Allam, 2017). The structure of hierarchical authorities with limited control and responsibilities ensure that in complex operations the interdependent factors are coordinated. It was planned to incorporate heterogeneous elements. A set of rules and procedures, the recruitment system and professional codes, calculated in order to give it complete control over all relevant information, have been provided to the decision maker. This model basically means exercising control to ensure that government management is centrally controlled and guided by the rule and regulation on a daily basis.

As the New Public Management (NPM) emphasized that, administrative reform is mainly about changing the administrative structures or procedures in public services that have become out of line with social and political expectations and values. Including eliminating waste, introducing new technologies, reorganization within the institution, increasing coordination and cooperation between them and redetermination functions, some aspects to boosting public activity are clearly administrative reform measures (Lim, Wang, and Lee. 2017).

Currently, the budgeting input method is absolute and the auditing mechanism is simply to verify that the budget for the line items allows all expenditure. Therefore, budgets are based partially on individual ministers ' political authority, and partly on the Budget Department's subjective judgment.

The budgeting process, which was for many years considered under control, has been disoriented by new and unexpected development. The increasing complexity and uncertainty of public budgeting have contributed to inflation, slower economic growth, increasing tax resistance, problems predicting revenues and expenses, budget deficits and public spending problems in addressing social problems. The loss of public trust in the government and its programs was accompanied by the obvious erosion in government budget control.

Responding to reform waves, long-term budget restructuring appears to be very necessary as budgeting practices are the result of interactions between several players. There is as much a relationship as a number of techniques in the budget process (ILO, 2015). Whatever techniques are adopted; these relationships will shape them. Techniques are also judged it is essential to choose the solutions traditional budget systems could not afford in the growing complex and turbulent field of financial management. For example, detailed monitoring of information costs and regulatory costs and 
the central policy direction against management independence need to be weighed. Budget reformers today are aware that in terms of an efficient budgetary environment their efforts have to be redirected somewhat differently from traditional budgetary concerns.

The government's expanded activities led to a significant increase in the budget and increased complexity in part as a result of the wide variety of activities and programs and in part as a result of changes in the nature of government payments (Kugler\&Kugler, 2009). At the same time, the results of expenditure have become difficult to evaluate because measures and indicators of objectives and objectives for real performance do not exist. Persistent budget deficits and perpetual annual increases in public spending raised fears that the state budget would not be in control.

Auditing the budget is generally defined in terms of the government's ability to make choices on the direction through the budget of government expenses (Duflo, 2012). Budgetary techniques are a way for other objectives only: control, accurate information, prioritization, coordinated decisionmaking process and decentralization. As the budgets have constantly changed in terms of their demands, budget reforms are always necessary. The type of change that the budget department generates is a change from focusing on government input, to focus on system accountability for the system results and outputs.

The study recommended that the reform efforts taken by the Ministry of Finance's Budget Department to implement performance budgeting in and reinforce the government's bureaucratic auditing mechanism and its activities to guarantee transparent, responsiveness and accountable government was:

1. There are a whole range of new tasks for existing departments in carrying out performance management reforms. The Ministry of Finance and the Budget Department are the key institutions used in managing reform efforts. However, there is a concern that the bureaucratic departments may resist a culture based on performance. In this situation, new specialist managers must be formed to complement current departmental standard activities. Reforms experiences and best practices showed that providing employees with the needed knowledge and skills in the reform process are important elements of change and cultural change in the implementation of reforms that are necessary for making them part of our routine working environment (OECD report 2008).

The cornerstone of such a reform is a performance information system containing audited data and information related to financial management. Outcomes, financial results, measures, or service quality or customer satisfaction surveys can be more emphasized. Performance measurement is also used by members of legislative authority or even the public as a tool for external accountability. Performance budget seen as a cumbersome exercise that requires constant monitoring and control. It is reinforcing the need for the executive and the legislative institutions to conduct a permanent audit, review and assessment of these systems.

2. Accountability issues can affect the use of a performance audit and its contents. In the context of a mechanism of accountability like audits, for example, market trials, privatization and the procurement of goods can influence. Because of this business model, some observatory argues that government should not allow market performance audits (Jacobsen, 2006).

This requires balance and complementarities in sustainable performance management between internal and external reviews.

In the case of Jordan, internally audit can be used as a catalyst for sharing good management practices and a training opportunity for potential leaders if the internal control structures have been transferred from the Ministry of Finance to the main departments. The Audit Bureau is also required to assess performance by assessing the mechanism for monitoring efficiency in order to prevent excessive bureaucratic or duplicate audit reports.

3. To build leverage for effective performance management, a series of results oriented management techniques need to be developed. Some of these methods involve agreements for results, benchmarking and best practices. Contracts or agreements establish accountability mechanisms, information flows and responsibilities. In South Korea for 
example, the ministers and the chief executives have an annual performance arrangement that reports directly with the government. This is complemented by annual purchases agreements for minister-agency output. Output is accountable to departments and agencies; output is accountable to ministers. Purchase contracts specify the outputs to be purchased and the conditions. The Minister is in charge of setting targets. Through quarterly ministerial reports and annual reports to parliament, agencies shall be held accountable.

Ultimately, performance budgeting inevitably stresses the management and policy consequences of public expenditure as the budget line is associated with monitoring procedures that some say is no longer sufficient at state levels. It takes too much time and does not allow policymakers and managers to choose between alternative allocations strategies. The use of budgetary performance is called a reform effort to connect finance to successful operations of the public departments. In the case of Jordan, departments must prepare their budget request with performance measures to assess the achievement of their objectives.

\section{References}

Agarwal, P. K. 2018. "Public Administration Challenges in the World of AI and Bots." Public Administration Review 78 (6): 917-921. doi:10.1111/puar.12979. [Crossref], [Web of Science ${ }^{\circledR}$ ], [Google Scholar

Biesbroek, R., B. G. Peters, and J. Tosun. 2018. "Public Bureaucracy and Climate Change Adaptation." Review of Policy Research 35 (6): 776-791. doi:10.1111/ropr.12316. [Crossref], [Web of Science ${ }^{\circledR}$ ], [Google Scholar]

Black den, M., and Mary Hallward-Driemeier, 2013, "Ready to Bloom?" Finance E Development, June (Washington: International Monetary Fund).

Blessett, B. 2018. "Social Justice in Public Administration: Moving with Intention to Disrupt the Status Quo." Public Administration Quarterly 42 (2): 123-126. [Google Scholar]

Boyd, N., and B. Nowell. 2020. "Public Service Motivation, Sense of Community, Sense of Community Responsibility, Organizational Commitment, and Identification: Testing an Integrated Model of Employee Well-Being and Engagement in a Public Service Work Context." Public Management Review. doi:10.1080/14719037.2020.1740301 [Taylor \& Francis Online], [Google Scholar]

Dias, J. J. and Maynard-Moody, S. (2007) For-Profit Welfare: Contracts, Conflicts, and the Performance Paradox. Journal of Public Administration Research and Theory, 17:2 pp189.

Duflo, E., 2012, "Women Empowerment and Economic Development," Journal of Economic Literature, Vol. 50 No. 4, pp. 1051-79.

FahedAlfanik, Reforming The Economic Security Committee, the Jordan Times, March 15, 2016.

Grimmelikhuijsen, S., S. Jilke, A. L. Olsen, and L. Tummers. 2017. "Behavioral Public Administration: Combining Insights from Public Administration and Psychology." Public Administration Review 77 (1): 45-56. doi:10.1111/puar.12609. [Crossref], [Web of Science ${ }^{\circledast}$ ], [Google Scholar]

ILO, (2015). "What Works in wage subsidies for young people: A review of issues, theory, policies, and evidence," Employment Working Paper No.199.

Kernaghan A (2010). Public Administration in the Canadian Encyclopedia: the Prelude to Government Reform in China: $\mathrm{p} 29$

Kugler, A. and Kugler, M. (2009), "Labor market effects of payroll taxes in developing countries: Evidence from Colombia" Economic Development and Cultural Change Vol.57 (2), pp. 335-358.

Larry Gerston. (2015). Public Policy-making, Routledge, New York, p5.

Light, P. 2019. "The Coming Showdown over Government Reform: How the Dismantlers and Rebuilders Will Shape the 2020 Election." Governance Studies. https://www.brookings.edu/research/the-coming-showdown-overgovernment-reform/ [Google Scholar]

Lim, S., T. K. Wang, and S. Y. Lee. 2017. "Shedding New Light on Strategic Human Resource Management: The Impact of Human Resource Management Practices and Human Resources on the Perception of Federal $\begin{array}{lllll}\text { Agency Mission Accomplishment." Public Personnel Management } 46 & \text { (2): 91-117. }\end{array}$ doi:10.1177/oog1026017704440. [Crossref], [Web of Science ${ }^{\circledR}$ ], [Google Scholar]

Miriam Allam. (2017). Governance in Transition: Efficient Machinery of Government. OECD. P15- 30

Nicholas Lawson, 2006, "The Colonial Origins of Comparative Development: An Empirical Investigation. "AmericanEconomic Review" 91 (5): pp1369- 1401.

OECD, 2008, Handbook on Constructing Composite Indicators-Methodology and User Guide, OECD publications. P 12-15 
Piatak, J. S., and S. B. Holt. 2019. "Prosocial Behaviors: A Matter of Altruism or Public Service Motivation?” Journal of Public Administration Research and Theory. doi:10.1093/jopart/muzo41. [Crossref], [Google Scholar]

Rami Tbaishat et al, (2018). Reforming policy roles in the Jordanian policymaking process, Journal of Public Affairs. Vol 19(1), P 6-8.

Stolk L and Wergrich K 2008. Convergence without Diffusion? A comparative Analysis of the Choice of Performance Indicators in the Tax Administration and Social Security International review of Administrative Sciences, 74(4):589.

Talbot, C. (2004) 'Executive Agencies: Have they improved Management in Government? Public Money and Management 24(2): 104-11.

Tbaishat Rami, (2015). Administrative Reform in Jordan: Urgency for Reforming the Bureaucracy Structure. Dirasat, Administrative Sciences, Vol 42, No 2, 2015, p 695.

The Bureau of Audit Law No. (28) Of 1952 and its amendments.

The Jordan Constitution Article 14.

UN Human Development Report, (2008)

UNDP Report, (2015) 'Executive Agencies: Have they improved Management in Government?

World Bank Ministerial Seminar, 2001, Amman Jordan, Jordan Institute of Public Administration. Pp197-201

World Bank Report, (2016) International Bank for Reconstruction and Development. What's holding back the Private Sector in MENA? Lessons from the Enterprise Survey. Pp 98- 105

World Bank Report. (2015). Jordan Economic Monitor, spring 2015: The Challenge Ahead. P 37. 